\title{
Growth of Purple Sulfur Bacterium Thiocapsa sp. Shira_1 at Low Temperatures Characteristic of the Chemocline of Lake Shira
}

\author{
Denis Y. Rogozin*a,b, \\ Vladimir V. Zykov and Maxim O. Tarnovsky ${ }^{\mathrm{a}}$ \\ ${ }^{a}$ Institute of Biophysics $S B$ RAS \\ FRC "Krasnoyarsk Science Center SB RAS" \\ 50/50 Akademgorodok, Krasnoyarsk, 660036, Russia \\ ${ }^{b}$ Siberian Federal University \\ 79 Svobodny, Krasnoyarsk, 660041, Russia
}

Received 22.09.2018, received in revised form 20.11.2018, accepted 10.12.2018

Forecasting the abundance of phototrophic sulfur bacteria in lakes is very important because 1) these bacteria are major consumers of hydrogen sulfide, and 2) fossil carotenoids of these bacteria are retrospective biomarkers of limnological conditions. Therefore, understanding the factors controlling the dynamics of the abundance of phototrophic sulfur bacteria in a lake is necessary both for the prediction of hydrogen sulfide content and for paleo-limnological reconstruction. Based on longterm monitoring of the abundance of purple sulfur bacteria (PSB) in the saline meromictic Lake Shira (South Siberia, Khakassia), we proposed a hypothesis that relatively small changes in water temperature in the cold deep chemocline affect the PSB abundance in the lake. We tested this hypothesis experimentally. The purple sulfur bacterium Thiocapsa sp. Shira_l (Chromatiaceae) from Lake Shira (South Siberia, Russia) was grown on a sulfide-containing synthetic medium under anoxic conditions in batch culture at low temperatures, from $-1^{\circ} \mathrm{C}$ to $+8^{\circ} \mathrm{C}$, which were similar to in situ temperatures observed in the chemocline of Lake Shira. The cell growth rate at $+8^{\circ} \mathrm{C}$ was similar to the growth rate at room temperature, whereas there was no growth at $-1^{\circ} \mathrm{C}$ and $+5^{\circ} \mathrm{C}$. Therefore, the variations in the biomass of purple sulfur bacteria (PSB) observed in Lake Shira could be caused by variations in chemocline temperature. The high correlation between chemocline temperature and PSB biomass supported this conclusion.

Keywords: purple sulfur bacteria, chemocline, temperature, batch culture.

Citation: Rogozin D.Y., Zykov V.V., Tarnovsky M.O. Growth of purple sulfur bacterium Thiocapsa sp. Shira 1 at low temperatures characteristic of the chemocline of Lake Shira. J. Sib. Fed. Univ. Biol., 2018, 11(4), 333-339. DOI: 10.17516/19971389-0076.

(C) Siberian Federal University. All rights reserved

This work is licensed under a Creative Commons Attribution-NonCommercial 4.0 International License (CC BY-NC 4.0).

* Corresponding author E-mail address: rogozin@ibp.ru 


\title{
Рост пурпурных серных бактерий Thiocapsa sp. Shira_1 при низких температурах,
} характерных для хемоклина озера Шира

\author{
Д.Ю. Рогозин ${ }^{\mathrm{a}, \tilde{\sigma}}$, В.В. Зыков ${ }^{\mathrm{a}}$, М.О. Тарновский ${ }^{\mathrm{a}}$ \\ ${ }^{a}$ Институт биофизики СО РАН \\ ФИЦ «Красноярский научный чентр СО РАН» \\ Россия, 660036, Красноярск, Академгородок, 50/50 \\ ${ }^{6}$ Сибирский федеральный университет \\ Россия, 660041, Красноярск, пр. Свободный, 79
}

Прогноз динамики численности фототрофных серных бактерий в природных стратифииированных водоемах признан важнойзадачей. Во-первых, данная группа бактерийосновной потребитель сероводорода, который является токсическим и бальнеологическим компонентом. Во-вторых, каротиноиды фототрофных серных бактерий, захороненные в донных отложениях, используются в качестве биомаркеров прошлых состояний озера. Таким образом, знание факторов, контролирующих активность фототрофных серных бактерий, необходимо как для прогноза конщентрации сероводорода, так и для палеоклиматических реконструкций. На основе многолетних наблюдений за динамикой численности пурпурных серных бактерий (ПСБ) в соленоммеромиктическом озере Шира (юг Сибири, Хакасия) нами была выдвинута гипотеза о том, что небольшие вариации температуры воды в холодном и глубоком хемоклине озера влияют на численность ПСБ. Для проверки этой гипотезы нами исследован рост штамма пурпурных серных бактерий Thiocapsa sp. Shira_1 из меромиктического соленого озера Шира в периодической культуре при температурах от минус 1 до $8{ }^{\circ} \mathrm{C}$, характерных для зоны хемоклина данного озера. Бактерий выращивали при постоянном освещееии в анаэробных условиях на синтетической среде с добавлением сероводорода. Показано, что рост данного штамма при $8{ }^{\circ} \mathrm{C}$ не отличался от такового при комнатной температуре, тогда как при температурах минус 1 и $5{ }^{\circ} \mathrm{C}$ достоверный рост отсутствовал. Результаты эксперимента свидетельствуют, что повымение температуры в зоне хемоклина озера до $8{ }^{\circ} \mathrm{C}$ является фактором, способствующим увеличению численности популящии этих бактерий в озере, что согласуется с многолетними наблюдениями.

Ключевые слова: пурпурные серные бактерии, хемоклин, температура, периодическая культура, культивирование.

\section{Introduction}

Purple sulfur bacteria (PSB), as well as green sulfur bacteria (GSB), are phototrophic microorganisms that perform anoxygenic photosynthesis using hydrogen sulfide and other reduced sulfur compounds as electron donors. Therefore, the ecological niche of these bacteria is associated with the presence of both sunlight and hydrogen sulfide. In the present-day biosphere, such conditions can be found in water or on the 
surface of bottom sediments of stratified water bodies: the sunlight penetrates to this depth, but oxygen is absent, while hydrogen sulfide, a product of bacterial sulfate reduction, is present. These conditions characterize the chemocline of meromictic lakes, at the upper boundary of the hydrogen sulfide zone (oxic-anoxic interface) (Gorlenko et al., 1977; Pfennig, Trüper, 1989).

It is extremely important to predict hydrogen sulfide concentration in such water bodies, as that hydrogen sulfide acts as a balneal component (Malakhov et al., 1963). To predict hydrogen sulfide concentration, one should be able to predict the activity of PSB, which are the main consumers of this compound. In Lake Shira, which experiences harsh continental climate and which is situated in southern Siberia (the North-Minusinsk Depression, the Republic of Khakassia), the chemocline zone is located at depths between 11 and $16 \mathrm{~m}$, where the water temperature remains low, $2-4^{\circ} \mathrm{C}$ on average, throughout the year. In some years, however, the temperature varies more widely, between $-0.5^{\circ} \mathrm{C}$ and $+8^{\circ} \mathrm{C}$, and PSB biomass changes as well (Rogozin et al., 2016). Thus, based on the correlation between PSB and temperature, we put forward the hypothesis that PSB in Lake Shira are sensitive to temperature variations within the range mentioned above. Because in nature, PSB activity may be influenced simultaneously by a number of important factors (light, $\mathrm{pH}$, salinity, etc.), we tested this hypothesis under controlled laboratory conditions.

The purpose of this study was to experimentally investigate PSB growth dynamics at low temperatures corresponding to the temperature range in Lake Shira and to determine whether bacterial cells responded to a rise in temperature of a few degrees Celsius near zero, e.g., to $+8^{\circ} \mathrm{C}$, with a statistically significant numerical increase. The experiment was performed with the PSB strain that dominated in
Lake Shira over the monitoring period, between 2002 and 2017 (Lunina et al., 2007; Rogozin et al., 2010; Rogozin, unpublished).

\section{Materials and Methods}

The experiment was performed with the strain of purple bacterium Thiocapsa sp. Shira_1 (Chromatiaceae), which we had previously isolated from the anaerobic zone of Lake Shira (AJ633676 in EMBL/GenBank) (Rogozin et al., 2010).

Bacterial cells were grown on a synthetic liquid medium imitating the ionic composition of Lake Shira, g L-1: $\mathrm{MgSO}_{4}-11.67 ; \mathrm{NaCl}-$ 2.24; $\mathrm{Na}_{2} \mathrm{SO}_{4}-7.43 ; \mathrm{MgCl}_{2}-0.22 ; \mathrm{CaCl}_{2}-0.2$; $\mathrm{KH}_{2} \mathrm{PO}_{4}-0.16 ; \mathrm{NH}_{4} \mathrm{Cl}-0.76 ; \mathrm{Na}_{2} \mathrm{~S}-0.099$; $\mathrm{NaHCO}_{3}-0.67$; vitamin $\mathrm{B}_{12}-0.02 ; \mathrm{Sl}_{12}-1 \mathrm{ml} \mathrm{L}^{-1}$ (Pfennig, Trüper, 1989).

Bacterial cells were cultured in 150-ml sealed glass syringes (Janet's syringes); the culture had been grown in a flask and inoculated into the syringes during the exponential growth phase, at a temperature of $+21^{\circ} \mathrm{C}$ (Fig. 1). The light source was a daylight fluorescent tube, and, thus, all syringes received equal amounts of light. Cultivation was conducted under continuous light, with light intensity on the surface of the syringes of $670 \mathrm{~lx}$. The syringes were placed into a bath containing a $6 \% \mathrm{NaCl}$ solution (to prevent freezing), and bath temperature remained constant through use of a KRIO-VT universal continuousflow cryostat (Termex, Russia). The temperature in the bath did not vary by more than $\pm 0.4^{\circ} \mathrm{C}$ during the experiment. A separate experiment with bacterial culture was conducted at each temperature $\left(-1,+5,+8^{\circ} \mathrm{C}\right)$. At a temperature of $-1{ }^{\circ} \mathrm{C}$, the experiment was run in triplicate (three syringes), and at temperatures of +5 and $+8^{\circ} \mathrm{C}$, the experiments were run in duplicate. In each experiment, to control viability of the cells, one additional (control) syringe was placed into a bath that contained the same salt solution but at 


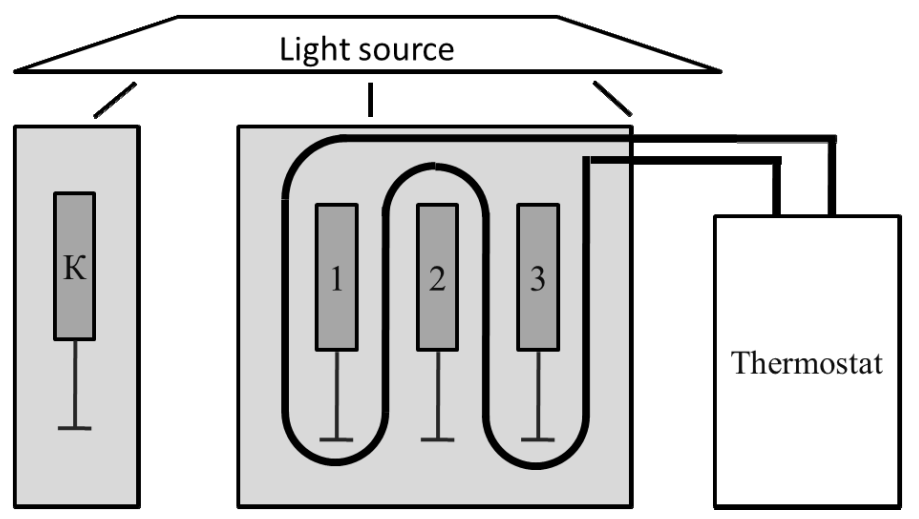

Fig. 1. A schematic diagram of the apparatus for cultivation of purple sulfur bacteria at low temperature. 1, 2, 3 - syringes submersed into the temperature stabilized $6 \% \mathrm{NaCl}$ solution. $\mathrm{K}$ is the reference syringe submersed into the $6 \% \mathrm{NaCl}$ solution at $+21^{\circ} \mathrm{C}$

a temperature of $21 \pm 1^{\circ} \mathrm{C}$, which is known to be favourable for this strain. Hydrogen sulfide was added as $5 \mathrm{ml}$ of the $3.5 \% \mathrm{Na}_{2} \mathrm{~S} \cdot 9 \mathrm{H}_{2} \mathrm{O}$ solution at the beginning of each experiment, simultaneously with the inoculation. Thus, in each experiment, both the treatment and control syringes were kept under the same conditions, with the exception of temperature. The experiment at the temperature of $-1^{\circ} \mathrm{C}$ was terminated earlier than the other experiments (at Day 6) due to failure of the thermostat.

To determine PSB cell numbers, samples of suspension were periodically removed from the syringes by pushing the plunger in. The number of cells was determined by converting suspension optical density to cell number. Optical density of suspension was measured using a UVIKON 943 spectrophotometer (Kontron, Italy), at a wavelength of $830 \mathrm{~nm}$, which corresponds to the absorption maximum of bacteriochlorophyll $a$ (Overmann et al., 1991). The conversion formula was obtained by linear regression of the data of microscopic counts. The cells were counted in four samples of suspension, which differed in their optical density (Fig. 2). To count cells, suspension was diluted by a factor of 30 with the synthetic medium supplemented with $0.6 \mathrm{ml}$ formalin. Two millilitres of each diluted suspension was passed through a black polycarbonate filter (pore size $0.2 \mu \mathrm{m}$ ). Cell nuclei were visualized using a solution of 4',6-diamidino-2-phenylindole (DAPI), $15 \mu \mathrm{m}$ of which was poured onto the filter and kept in the dark room for $20 \mathrm{~min}$. For each of the four samples of suspension with the measured optical density, cells were counted in 20 different fields of the filter at $\times 1000$ magnification under a CarlZeiss FL40 fluorescence microscope. Cell numbers in the graphs are given as the means \pm standard deviation of the mean for $\mathrm{P}=0.95$. Statistical significance of bacterial growth was estimated using single-factor analysis of variance with F-test at 95\% confidence level (Lakin, 1980). Statistical analysis was done using STATISTICA 10 software.

\section{Results and Discussion}

The relationship between the optical density of cell suspension and cell number was adequately described by the linear function $\left(r^{2}=0.85\right)$ (Fig. 2), justifying the use of the spectrophotometric method to estimate the number of PSB cells in this experiment.

Using linear regression, we obtained a formula for calculating the number of cells for probability $\mathrm{P}=0.95$ : 


$$
X=(29.41 \pm 1.45) O D_{830}-(1.57 \pm 0.55)
$$

where $X$ is cell number $\left(10^{6}\right.$ cells $\left.\mathrm{ml}^{-1}\right)$ and $O D_{830}$ is optical density of the suspension.

In each experiment, a significant increase in cell numbers was observed in control syringes in the first $36 \mathrm{~h}$ (Fig. 3), suggesting that the composition of the medium was favourable for cell growth and that the inoculum was sufficiently physiologically active. At temperatures of $-1^{\circ} \mathrm{C}$ and $+5^{\circ} \mathrm{C}$, no significant increase in cell numbers was noted, suggesting the unfavourable effect of the low temperatures in this range on cell growth (Fig. 3 A, B). However, cells grown at $+8^{\circ} \mathrm{C}$ showed a significant numerical increase, which was comparable to that observed in the control syringe (Fig. 3 C). Specific growth rate, estimated on the assumption of exponential growth, was approximately $0.04 \mathrm{~h}^{-1}$ at $+8^{\circ} \mathrm{C}$ and $+21^{\circ} \mathrm{C}$ in the first $12 \mathrm{~h}$. In all syringes where cell numbers had been increasing, cell growth slowed down or stopped after $48 \mathrm{~h}$, likely because of sulfide depletion (sulfide concentration in the syringes was not measured), the self-shading effect in the dense culture, and other possible bottle effects (changes in the composition of the medium, $\mathrm{pH}$, etc.) that occur in batch culture.

Thus, the present study shows that the PSB strain tested in experiments is sensitive to the insignificant temperature variations in the

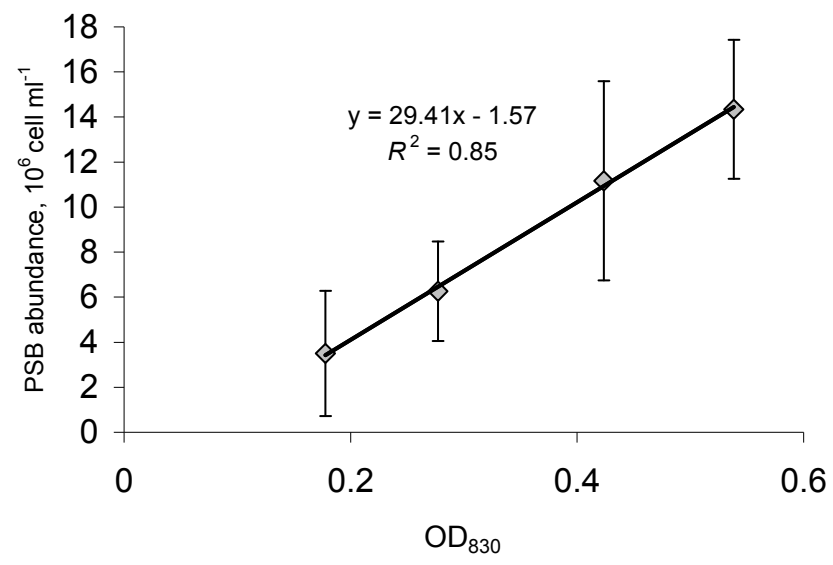

Fig. 2. Abundance of purple sulfur bacteria vs. optical density at $830 \mathrm{~nm}$
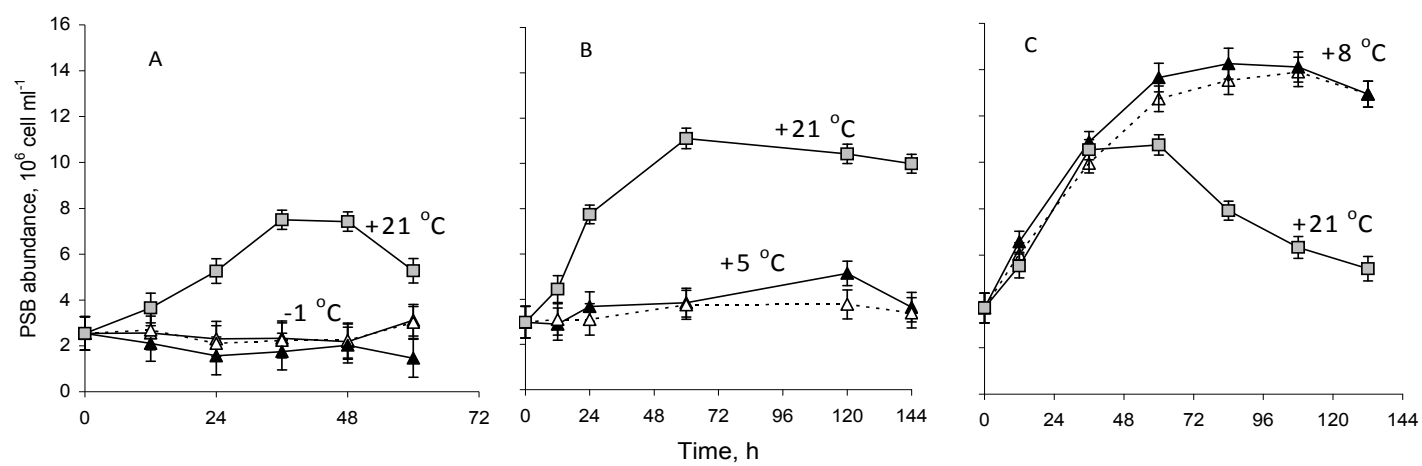

Fig. 3. Dynamics of PSB abundance in three experiments at different temperatures: $\mathbf{A}:-1^{\circ} \mathrm{C} ; \mathbf{B}:+5^{\circ} \mathrm{C} ; \mathbf{C}:+8^{\circ} \mathrm{C}$; in each experiment, the reference sample was cultivated at $+21^{\circ} \mathrm{C}$ 
chemocline of Lake Shira, and its growth rate at $+8^{\circ} \mathrm{C}$ is similar to that at room temperature. The experimental data reported in a study by Parker et al. (1983) suggested that specific growth rate of the PSB Lamprocystis roseopersicina, whose ecophysiological and phylogenetic characteristics are similar to those of our strain, increased by a factor of 1.3 as the temperature rose from $0^{\circ} \mathrm{C}$ to $+5^{\circ} \mathrm{C}$ and decreased at $+15^{\circ} \mathrm{C}$. However, we have not found any experimental data for temperatures below $0^{\circ} \mathrm{C}$, and a more exact optimal temperature for that strain is not known.

The similar growth rates of our strain at $+8^{\circ} \mathrm{C}$ and at room temperature (Fig. $3 \mathrm{C}$ ) suggest that our strain has adapted to low temperatures characteristic of its habitat. However, at or below $+5^{\circ} \mathrm{C}$, no growth is noted, suggesting this strain is very sensitive to small temperature variations in the range characteristic of the chemocline of Lake Shira.

In a previous study, we showed that PSB numbers in Lake Shira correlated positively with the temperature in the chemocline; namely, PSB numbers were extremely low in 2010 , at $-0.5^{\circ} \mathrm{C}$, and, by contrast, exceptionally high in 2007 , at $+8^{\circ} \mathrm{C}$ (Rogozin et al., 2016). A significant positive correlation between the temperature in the chemocline and PSB numbers was observed both in the season when the water was covered with ice and in the open water season. The highest temperature was recorded in summer 2007 (about $+8^{\circ} \mathrm{C}$ ) and the lowest in winters of 2003, 2010, and $2012\left(-0.5^{\circ} \mathrm{C}\right)$; in 2003 and 2010 , the temperature did not rise above $0^{\circ} \mathrm{C}$ even in summer (Rogozin et al., 2016).

Temperature variations were caused by yearto-year variations in mixing of water masses, which was confirmed by strong correlation between temperature and conductivity (Rogozin et al., 2016). Conductivity, which is a function of salinity, varies in the chemocline during the yearly cycle, when the lowest layers, which contain more salt, are mixed with the upper layers, which have lower salt content, as described in a number of Lake Shira studies (Rogozin et al., 2016, 2017). As temperature is not an independent factor, one cannot assert that it is the only factor directly influencing PSB production in the lake, but results of our experiment show that this influence is possible if all other conditions remain the same (light, conductivity, hydrogen sulfide concentration, $\mathrm{pH}$, etc.).

Thus, experimental research showed that at temperatures of $-1{ }^{\circ} \mathrm{C}$ and $+5^{\circ} \mathrm{C}$, the PSB strain from Lake Shira did not exhibit growth, while at $+8^{\circ} \mathrm{C}$, the strain demonstrated significant growth comparable to its growth at room temperature. This result confirms the hypothesis that temperature variations between $-0.5^{\circ} \mathrm{C}$ and $+8^{\circ} \mathrm{C}$ in the chemocline of Lake Shira could cause changes in PSB numbers recorded in the lake (Rogozin et al., 2016). These results will be useful for constructing predictive mathematical models that take into account dynamics of PSB as the major consumer of hydrogen sulfide.

\section{Acknowledgements}

The authors are grateful to the two anonymous reviewers for their valuable comments, which have led to significant improvements of the manuscript. This study was supported by RFBR (Project No. 16-05-00091) and Integrated Program for Basic Research of SB RAS II.1 (Project "Biophysical and lithological-geochemical responses of lake sedimentation systems on climate change in the late Holocene").

\section{References}

Gorlenko V.M., Dubinina G.A., Kyznetsov S.I. (1977) Ecology of aquatic microorganisms. Moscow, Nauka, 287 p. (in Russian) 
Lakin G.F. (1980) Biometry. Moscow, Vysshaya Shkola, 293 p. (in Russian)

Lunina O.N., Bryantseva I.A., Akimov V.N., Rusanov I.I., Barinova E.S., Lysenko A.M., Rogozin D.Yu., Pimenov N.V. (2007) Anoxygenic phototrophic bacteria community of Lake Shira (Khakassia). Microbiology, 4: 469-479

Malakhov A.M., Skornyakov V.A., Tsytsarin G.V. (1963) Hydro-mineralogical resources of the spa Lake Shira. Matherials on the research of therapeutic mud, mud lakes and sources. Moscow, Central research institute of balneology and physiotherapy, p. 51-151 (in Russian)

Overmann J., Beatty T., Hall K., Pfennig N., Northcote T. (1991) Characterization of a dense, purple sulfur bacterial layer in a meromictic salt lake. Limnologica, 5: 846-859

Parker R.D., Lawrence J.R., Hammer U.T. (1983) A comparison of phototrophic bacteria in two adjacent saline meromictic lakes. Hydrobiologia, 105: 53-62

Pfennig N., Trüper H. (1989) Anoxygenic phototrophic bacteria. Bergey's manual of systematic bacteriology. Staley J.T., Bryant M.P., Pfennig. N., Holt J.G. (eds.) Baltimore, Williams and Wilkins, p. $1635-1653$

Rogozin D.Y., Trusova M.Y., Khromechek E.B., Degermendzhy A.G. (2010) Microbial community of the chemocline of meromictic Lake Shunet during summer stratification. Microbiology, 2: 253-261

Rogozin D.Y., Zykov V.V., Tarnovsky M.O. (2016) Dynamics of purple sulfur bacteria in saline meromictic Lake Shira (Khakasia, Siberia) for the period 2007-2013. Microbiology, 1: 93-101

Rogozin D.Y., Tarnovsky M.O., Belolipetskii V.M., Zykov V.V., Zadereev E.S., Tolomeev A.P., Drobotov A.V., Barkhatov Y.V., Gaevsky N.A., Gorbaneva T.B., Kolmakova A.A., Degermendzhi A.G. (2017) Disturbance of meromixis in saline Lake Shira (Siberia, Russia): possible reasons and ecosystem response. Limnologica, 66: 12-23 